\title{
A needs assessment for consumer learning at a higher education institution
}

\author{
Sharon Crafford and Eli Bitzer
}

\begin{abstract}
Opsomming
Hierdie artikel is gebaseer op ' $n$ studie wat onderneem is om die behoefte vir kurrikulumontwikkeling vir verbruikersleer aan die Kaapse Skiereilandse Universiteit van Tegnologie te bepaal.
\end{abstract}

Die Verenigde Nasies het reeds in 1985 ' $n$ beroep op opvoeders gedoen om verbruikersleer wêreldwyd te bevorder en toepaslike opvoedkundige programme te ontwikkel wat sensitief is vir kulturele tradisies. In die snelveranderende en komplekse verbruikersmark van vandag is dit veral tieners en jong volwassenes wat kennis en vaardighede benodig om ingeligte besluite te kan neem. Verbruikersbesluite waarmee hulle gekonfronteer word, sluit kwessies in soos finansies, lewenstylkeuses, bepaling van waardes, billike handelspraktyke en omgewingsbewaring.

Internasionale studies toon dat daar ' $n$ behoefte aan verbruikersleer bestaan, veral onder tieners en jong volwassenes. Kurrikula op skool verskaf egter nie genoegsame agtergrond en inligting om individue toe te rus om ingeligte en verantwoordelike verbruikersbesluite te neem nie. ' $n$ Gebrekkige kennis van verbruikersregte en -verantwoordelikhede blyk ook ' $n$ ernstige tekortkoming te wees. In Suid-Afrika speel historiese faktore inmiddels ' $n$ groot rol in die gebrek aan kennis van en ervaring in verbruikerswese.

Die artikel fokus op ' $n$ studie wat onderneem is met die oog op 'n behoeftebepaling vir verbruikersleer aan 'n spesifieke hoëronderwysinstelling as 'n SuidAfrikaanse gevallestudie. Die studie het insigte oor die behoefte aan verbruikersleer binne die bepaalde instelling verbreed en terselfdertyd bygedra tot die ontwikkeling van 'n kurrikulumraamwerk wat kan dien as ' $n$ basis vir kurrikulumontwikkeling vir verbruikersleer in hoër onderwys.

Empiriese gegewens is verkry vanuit ' $n$ self-geadministreerde opnamevraelys wat deur middel van ' $n$ dendrogram saamgestel is. Die dendrogram wat as basis vir die konsepsuele raamwerk gedien het, is na 'n deeglike literatuuroorsig ontwikkel. Die vraelys het vrae ingesluit om die kennis, gebruike en persepsies van respondente ten opsigte van verbruikersregte en -verantwoordelikhede te bepaal. Tydens die ontwikkeling van die vraelys is tien vakdeskundiges betrek om die inhoud- en gesigsgeldigheid daarvan te toets. Nadat voorgestelde veranderinge aangebring is, is die opname-instrument deur 45 eerstejaar- Somatologiestudente in die Fakulteit vir Toegepaste Wetenskappe aan die Kaapse Skiereilandse Universiteit van Tegnologie (KSUT) in 'n loodsfase voltooi. Geen verdere wysigings was nodig nie. Doelbewuste steekproefneming is toegepas en 474 uit 'n getal van 5850 geregistreerde eerstejaarstudente is gekies om die vrae- lys te voltooi. Studente is uit die Fakulteite van Toegepaste Wetenskappe, Bestuurswese, Ingenieurswese en Opvoedkunde gekies sodat vergelykings tussen fakulteite gemaak kon word.

' $n$ Empiries-analitiese benadering is gevolg met die ontleding van die eerstejaarstudente se antwoorde. Kodifisering is gebruik om antwoorde vanuit die oop vrae te kategoriseer. Geslote, veelvuldige keuse en binominale vrae, asook ' $n$ Likertskaal-vraag is in die vraelys ingesluit.

Die ontleding van die resultate toon dat die meerderheid $(79,5 \%)$ eerstejaarstudente aan die KSUT aandui dat daar by hulle ' $n$ behoefte aan verbruikersleer bestaan. Vanuit die resultate is aanbevelings ten opsigte van kurrikulumontwikkeling vir verbruikersleer met die klem op verbruikersregte en verantwoordelikhede gemaak. Insgelyks blyk dit dat ouer en swart studente die groep te wees wat die meeste uit institusionele opleiding in verbruikersleer sal baat. Van die aanbevelings sluit in dat studente meer blootstelling aan gespesialiseerde publikasies wat fokus op ekonomiese sake moet verkry, asook meer kennis oor klagtes en klagteprosedures wat gevolg kan word. Die belangrikheid van media, veral televisie om verbruikersregte en -verantwoordelikhede te beskerm moet ingesluit word; so ook die kritiese belang van verbruikersleer as verbruikersreg. Die belangrike rol van verbruikersorganisasies ten opsigte van die beskerming van verbruikersregte, asook inligtingbronne, veral die Internet, wat geraadpleeg kan word voor besluitneming, moet in enige toekomstige leerprogram beklemtoon word.

Die vraelysopname het dus getoon dat daar " $n$ behoefte aan verbruikersleer onder eerstejaarstudente aan die KSUT bestaan. Die studie het verder bygedra tot die ontwikkeling van ' $n$ kurrikulumraamwerk vir verbruikersleer wat versoenbaar is met die vereistes van die Suid-Afrikaanse Kwalifikasie-Owerheid en dié van die Hoëronderwys-Kwalifikasieraamwerk in Suid-Afrika. Daar word voorsien dat die behoeftebepaling as vertrekpunt kan dien vir die kurrikulering van verbruikersleerprogramme in hoëronderwysinstellings in Suid-Afrika, en moontlik ook wyer in Afrika aangesien Afrikane self die beste toegerus is om eiesoortige leerstrategieë te ontwikkel ten einde toekomstige verbruikers, waarvan hoëronderwysbevolkings ' $n$ uiters belangrike komponent is, te bemagtig.

\section{- Dr Sharon Crafford}

Department Agricultural and Food Sciences Cape Peninsula University of Technology

\section{- Prof Eli Bitzer}

Centre for Higher and Adult Education

Faculty of Education, University of Stellenbosch 


\section{INTRODUCTION}

Consumer learning is concerned with acquiring the skills, attitudes, knowledge and understanding that will enable individuals in a consumer society to make full use of the range of consumer opportunities present in a complex marketplace. In consumer-driven societies it has become essential to promote consumer competence and consumer learning - particularly among young people who are the consumers of tomorrow. (Atherton \& Wells, 1998; Bannister \& Monsma, 1982:5; NICE-Mail 18, 2002). Teenagers and young adults have to deal with many consumer-related issues and these are often the times when they need consumer knowledge and information the most. Various matters, such as decisions concerning finances, issues of lifestyle, and values involving consumerism, fair trade and environmental responsibility, demand that young adults have knowledge and information of the market (Lachance \& Choquette-Bernier, 2004; NICE-Mail 19, 2003).

An important call by the Economic and Social Committee of the United Nations (UN) in 1985 has alerted educationalists to the need for developing consumer learning worldwide. The adopted 'Guidelines for Consumer Protection' were subsequently expanded in 1999, and the section devoted to consumer learning and information reads as follows: "Governments should develop or encourage the development of general consumer education (learning) and information programmes, bearing in mind the cultural traditions of the people concerned. The aim of such programmes should be to enable people to act as discriminating consumers, capable of making informed choice of goods and services, and conscious of their rights and responsibilities. In developing such programmes, special attention should be given to the needs of disadvantaged consumers in both rural and urban areas, including low-income consumers and those with lower or non-existent literacy levels" (United Nations, 1985: Chapter F, paragraph 31; United Nations, 2003).

Hayward and Coppack (2001:51) contend that in a fast changing and complex marketplace, consumers need more than merely information and advice. They also need the skills to be able to analyse and use both. Consumer learning therefore involves cognitive skills to help students make informed decisions, but it also implies an understanding of the impact of individual, business and government decisions on the lives of others. Affective learning, giving rise to an awareness that it is important to act and behave sensitively, should also be achieved (Hellman-Tuitert, 1999:14).

Financial assistance was received from the Cape Peninsula University of Technology.

The article is based on a dissertation presented for the Degree of Doctor of Philosophy in the Faculty of Education at the University of Stellenbosch December 2006.
Surveys indicate a global lack of knowledge and skills that would enable individuals to act as informed and intelligent consumers (Bannister,1996; NICE-Mail 1, 1994; NICE-Mail 15, 2001). For instance, a survey by the Consumer Federation of America (CFA) found that many Americans did not understand credit reports and credit scores. The survey emphasises a crucial need for education on consumer rights, to read credit reports, to correct errors in credit reports and how a credit score is determined (Givens, 2004). In the same vein, research conducted by Rousseau (1999:386) on consumer awareness had revealed a serious need for consumer learning among South Africans. Rousseau (1999:375) contends: "African consumers are not only unaware of their rights, but are also uninformed about the exploitive nature of the market and the quality and safety of the goods that the suppliers are selling to them."

Students, being an important group of both current and future consumers, particularly from previously disadvantaged backgrounds, have to face problems such as marginalisation, poverty, unemployment, illiteracy, lack of education and limited resources. They, as much as their supposedly "privileged" peers, are in most instances ill prepared for active participation as informed and responsible consumers in the marketplace and are vulnerable targets for exploitation. It is no suprise that authors like Chan (2001) point to the fact that vulnerable young adults need to be provided with awareness-raising consumer learning and skills development opportunities regarding their consumer rights, namely access to the means of meeting basic needs, the right to safety, the right to be informed, the right to choose, the right to be heard, the right to redress, the right to consumer learning and the right to a healthy environment. To these may be added the responsibilities of social concern, solidarity, critical awareness, action and involvement and environmental awareness (Consumers International, 1999, 2003).

In the South African Qualifications Authority (SAQA)based Further Education and Training (FET) curriculum (Grades 10-12), Consumer Learning, which forms part of the Consumer Studies curriculum in South Africa (SA), will not be compulsory (Department of Education (DoE), 2005). This may create a situation where many school leavers attending higher education institutions may have limited or no exposure to consumer issues in their educational background. As more students gain access to higher education in a post-apartheid era, serious problems in adjusting to higher education may be experienced. These problems may relate to inadequate levels of literacy, numeric and communication skills (Bitzer 2003, 2005; Bitzer \& Troskie-De Bruin, 2004). Students are often confronted by academic-related challenges, which are frequently compounded by consumer-related problems such as exploitative sales ploys that could lead to debt, buying faulty goods and receiving poor service; the urgent need for consumer learning in higher education seems apparent.

Consumer learning does not only have the potential to assist young adult consumers in the short term to ad- 
dress their immediate needs, but also to prepare them for becoming the informed consumers of tomorrow. Coppack (2002:51) states aptly that "...something must be done now to enable adults to make the right decisions during the different life stages, throughout life".

\section{PURPOSE OF THE RESEARCH}

The major aim of the study was to determine the need for consumer learning at the Cape Peninsula University of Technology (CPUT) through the use of a selfadministered survey questionnaire focusing on the knowledge, practices and perceptions of first year (National Qualifications Framework: Level 5) students regarding consumer rights and responsibilities. The following working definition of 'consumer learning', based on the work of several authors (Bannister \& Monsma, 1982; Hellman-Tuitert, 1999:15; Steffens, 1993:22) was taken as a point of departure: "Consumer learning is the process of gaining knowledge and understanding, skills, values and attitudes to create critical, independent thinking and informed consumers who not only manage consumer resources responsibly in a complex, multi-faceted society, but take appropriate action to influence the factors which affect consumer decisions as part of collective life". This information furthermore assisted in the development of a curriculum framework for consumer learning which is compatible with the requirements of the South African Qualifications Authority (SAQA) and the Higher Education Qualifications Framework (HEQF) (Crafford, 2006: 217).

\section{METHODOLOGY}

\section{Target group}

The envisaged target group consisted of approximately 500 students from the total population of 5850 registered first-year students at the CPUT in 2004. Purposive or judgmental sampling as a non-probability technique was used. This technique is applied when the researcher has some background information regarding the population and deliberately selects people and events that are likely to produce the most valuable data (Babbie, 1990:97; Denscombe, 2001:15; Struwig \& Stead, 2001:111). It is important to note that the projection of data beyond the sample would be statistically inappropriate as variability and bias of estimates cannot be controlled or measured (Struwig \& Stead, 2001:111,115). This, according to Stoker (1989:103), does not imply that good results cannot be achieved with non-probability methods.

\section{Questionnaire design}

The survey questionnaire was based on a dendrogram (Schutte, 1992). This technique was applied after the boundaries for the theory were defined during a comprehensive literature study and acted as a guide for compiling the relevant survey questions. The assumption that was made at the onset of the devel- opment of the survey questionnaire was that university students (as young adults) would possess prior knowledge and be informed regarding consumer rights and responsibilities. The questions covered knowledge of consumer rights and responsibilities, purchasing practices, knowledge of SA consumer organizations and information sources, the need for consumer learning and biographical information. It was decided to use the term "consumer education" instead of "consumer learning" in the questionnaire as this terminology was thought to be more familiar to students.

The order of the questions was based on the internal logic of the enquiry and the likely reaction of the respondents. Each question was concerned with a specific variable. The various question formats that were included in the content domain varied according to the type of information required (Schnetler, 1989:45). Question types included were open-ended, closed, i.e. multiple choice, dichotomous and a Likert-scale response question. A funnel approach as suggested by Oppenheim (1992:110), Babbie (1992:154) and Huysamen (1994:133) was used in the construction of the questions. According to this approach, a broad question is asked and then progressively narrows down the scope of questions till it ends in some specific point. Filter questions or contingency questions were used to exclude some respondents from a particular question sequence irrelevant to them. Clear routing instructions were given to respondents to skip questions and proceed to the beginning of a next sequence.

There is no general consensus on the positioning of demographic questions. Of importance, however, is that questions are ordered in a way that is logical and seems natural to the respondent (Singleton et al, 1993:311). In this study biographical questions were placed towards the end of the questionnaire.

\section{Informal feedback and pre-testing of questionnaire}

Informal feedback and pre-testing were used to increase instrument validity. Ten colleagues and specialists familiar with the nature and scope of the study were asked to comment informally on the content and face validity of the questionnaire, as well as on its question construction methodology. Recommended modifications made included simplification of terminology, the restriction of open-ended questions and shortening of the questionnaire. The final version was a user-friendly booklet with 20 questions that reflected the logic of the conceptual framework.

As a pre-test, a class of 45 first-year Somatology students in the Faculty of Applied Sciences at the CPUT was asked to complete the questionnaire. No students indicated problems with the question construction or the interpretation thereof and a $100 \%$ completion rate was achieved. An analysis of responses indicated, however, that a small percentage of students did not answer the funnel questions correctly as they did not follow the instructions properly. These instructions were thus emphasised by highlighting them in the final questionnaire. 


\section{Data collection}

The survey was conducted over a two-week period during the last quarter of 2004. Seven registered first year class groups (Civil Engineering, Personnel Management, Marketing, Education, Somatology, Food Technology, Consumer Science: Food and Nutrition) from four faculties (Applied Sciences, Management, Engineering and Education) at the CPUT participated. The total number of respondents was 474 and all the completed questionnaires could be used.

\section{Data analysis}

An empirical-analytical approach was used to analyse the questionnaire responses. Coding was used as a method of conceptualising data and classification into meaningful and relevant categories. The data was entered into an Excel spreadsheet and then imported into a STATISTICA data analysis software system (Statsoft, Inc., 2005). Descriptive statistics such as frequencies of variables, differences between variables and averages were mostly used to analyse the data (Singleton et al, 1993:425-426). Statistical tests such as the Pearson chi-square test was used to estimate the significance of the results and the probability that they did not occur by chance.

To achieve a more structured knowledge index for respondents, a decision was taken to calculate a total knowledge index for respondents for the first three open-ended questions on the questionnaire. If respondents answered all three questions correctly, a score of three was allocated, which meant that the student had good knowledge. A score of two was allocated if a respondent had two of the three questions correct, which indicated that the student had average knowledge. A score of one was allocated if any one of the three questions was correct, which meant that the respondent had little knowledge. A score of zero was allocated if the respondent had no answers correct, or if the response was omitted, meaning no knowledge of the three topics.

\section{RESULTS AND DISCUSSION}

\section{Biographical information}

Most respondents $(62,7 \%)$ were female. More than half $(51,1 \%)$ were between the ages of 20 to 25 with few $(4,0 \%)$ older than 25 . Females tended to be younger (49,2\% were 19 years and younger). Most respondents $(30,6 \%)$ were studying at the Faculty of Management, followed by the Faculties of Applied Sciences (25,7\%), Engineering (23,0\%) and Education $(18,4 \%)$. Most male respondents were in the Faculty of Engineering (46,9\%), followed by the Faculty of Management $(35,8 \%)$. Most of the female respondents were in the Faculty of Applied Sciences $(35,4 \%)$, followed by the Faculty of Management $(29,3 \%)$ and Education (25,3\%). In terms of age, most students older than 26 years $(42,1 \%)$ were in the Faculty of Education.
Nearly half $(49,6 \%)$ of the respondents were Englishspeaking, followed by those speaking an African language $(24,5 \%)$ and those with Afrikaans as home language $(22,2 \%)$. More females than males $(58 \%$ and $40,6 \%$ respectively) spoke English, whereas approximately the same number of males and females spoke an African language (26,3\% and $24,6 \%$ respectively). A third of the respondents who spoke Afrikaans $(33,1 \%)$ were males, and only $17,4 \%$ were females.

The results for language distribution by age indicate that the older the group (26 years and older), the larger the percentage of African language respondents. In the English-speaking group, which represented $51,6 \%$ of the total group, the largest percentage was between 20 and 25 years of age. The largest percentage $(29,6 \%)$ of students younger than 19 years of age was Afrikaans-speaking.

In terms of subjects taken at school or university which would be relevant to consumer learning, 51,9\% of the respondents studied Accounting, followed by 43\% with Business Economics, 34\% with Home Economics and $26,6 \%$ with Business Management. Very few students studied Consumer Behaviour (9,7\%) and Financial Management $(6,3 \%)$. With respect to gender, more females than males were exposed to the specific subjects. This was expected as females represented about two thirds $(62,7 \%)$ and males approximately a third of the students $(34,8 \%)$.

\section{Consumer rights and responsibilities}

Knowledge of consumer rights and responsibilities The first three questions of the questionnaire were open-ended. It was decided that these three questions would give an indication of the existing knowledge of respondents regarding consumer rights and responsibilities at the onset of the questionnaire. The questions were as follows:

1. "If you think of consumer rights, what comes to mind first?"'

2. "If you think of consumer responsibilities, what comes to mind first?"

3. "What is the single most important consumer advice you would give your best friend?"

The total knowledge index that summarised these responses (Questions 1, 2 and 3) indicated that 27,2\% had good knowledge (all three answers correct), while $30,2 \%$ had at least two of the three questions correct. This means that $57,4 \%$ (nearly $60 \%$ ) of the respondents had at least two out of three questions correct. About $15 \%(15,3 \%)$ of the respondents received scores pertaining to having no knowledge of consumer rights and responsibilities.

In the case of the total knowledge index and age, a somewhat problematic situation arose. The Pearson chi-square test showed a significant association between the index and age $\left(X^{2}=14,8\right.$, d.f. $=6, p=$ $0,237)$. Due to the small expected values, the maximum likelihood ratio (MLR) statistic was also computed $(G=11,5$, d.f. $=6, p=0,744)$. The MLR test did not indicate significance. Both the $p$-values were exact 
(and not asymptotic) and led to opposite conclusions. It was thus decided to do a graphical presentation of the table by means of a correspondence analysis (Greenacre, 1984:54-66). The three age groups were plotted in the best fitting two-dimensional subspace of the four-dimensional knowledge space. The first dimension explained $81,6 \%$ of the total inertia of the table (i.e. it was responsible for that percentage of the chi-square value for the table). The second dimension added another $18,5 \%$ (percentages were rounded) and thus a very good visual picture was achieved in two dimensions (Figure 1).

A conspicuous feature of the figure is that the point representing the older group of students differs dramatically on the first dimension from the other two groups. From the correspondence analysis and visual inspection of Figure 1, it is clear that the older the respondents are, the less knowledge they have about consumer issues $(42,1 \%$ having no knowledge). A reason for this could be related to the subject choice at school and university level, which provided limited exposure to consumer learning.

The result of the total knowledge index per faculty indicated that the Faculty of Applied Sciences obtained good knowledge scores ( $81,1 \%$ for good knowledge and average knowledge responses), followed by the Faculties of Management $(56,5 \%)$, Education $(44,8 \%)$, and lastly Engineering $(40,4 \%)$. The total knowledge index by language indicated that Englishspeaking respondents had the most knowledge (65,1\%: good + average knowledge), followed by Afrikaans-speaking respondents $(53,3 \%)$ and finally the African language group (45,7\%), who had the lowest score.

Expression of consumer rights The next question posed was: "How confident are you about expressing your rights as a consumer?" More than half $(57,8 \%)$ of the respondents were confident to very confident $(23,4 \%)$ about expressing their rights as a consumer; only $16,2 \%$ were not confident. The results, which are summarised in Table 1, indicated that respondents from the Faculty of Engineering were the most confident $(93,7 \%)$ in their expression of consumer rights followed by respondents from the Applied Sciences $(81,5 \%)$, Management $(79,6 \%)$ and lastly the Education $(76,1 \%)$ Faculties. It is interesting to note that although the respondents from the Faculty of Engineering had the least knowledge regarding consumer rights, they had more confidence in expressing these rights.

Consumer right to basic needs provision The next question "To what extent do you feel your consumer rights with respect to the quality of basic needs (food, housing, clothing, healthcare, education and drinking water) are protected in South Africa?" was included to determine the perception of respondents regarding this right. Most respondents (78,5\%) felt protected to some extent, while only a small percentage $(12,6 \%)$ felt that they were protected to a full extent. The female respondents $(93,8 \%$ for some extent and full extent responses) were more satisfied than the male respondents $(86.1 \%)$ in this regard. Younger respondents in the group (19 years and younger) felt more positive $(83,0 \%)$ than the other respondents. Some African home language respondents $(20,7 \%)$ tended to be of the opinion that their basic needs were fully met, followed by English-speaking (10,3\%) and Afrikaans-speaking respondents (8,7\%).

The next question was: "Do you think South African consumers have reasonable access to a variety of products/services at reasonable prices?" The perception of the majority of respondents $(62,8 \%)$ was positive. Females were more satisfied $(93,8 \%$ for some extent and full extent responses) than males $(86,1 \%)$ about access to products and services at reasonable prices.

Awareness of consumer education as a consumer right To determine the awareness of respondents

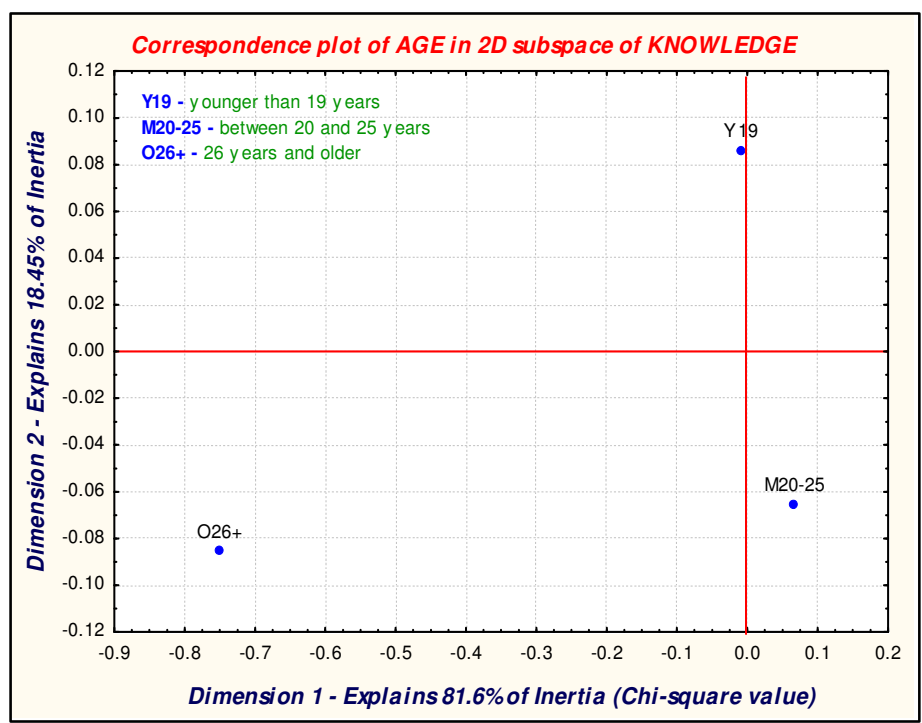

FIGURE 1: CORRESPONDENCE PLOT OF RESPONDENT AGE IN SUBSPACE OF THEIR KNOWLEDGE 
TABLE 1: RESPONDENT CONFIDENCE IN EXPRESSING CONSUMER RIGHTS BY FACULTY

\begin{tabular}{|l|c|c|c|c|c|c|c|c|c|c|}
\hline & \multicolumn{2}{|l|}{ Education } & \multicolumn{2}{|l|}{ Engineering } & \multicolumn{2}{|c|}{ Management } & \multicolumn{2}{|c|}{ Applied Sciences } & \multicolumn{2}{|c|}{ Total } \\
\hline Consumer rights & $\mathbf{N}$ & $\%$ & $\mathbf{N}$ & $\%$ & $\mathbf{N}$ & $\%$ & $\mathbf{N}$ & $\%$ & $\mathbf{N}$ & $\%$ \\
\hline Not confident & 29 & 24,0 & 9 & 6,3 & 22 & 20,4 & 15 & 18,5 & 57 & 16,6 \\
\hline Confident & 71 & 58,7 & 97 & 68,3 & 58 & 53,7 & 45 & 55,6 & 271 & 60,0 \\
\hline Very confident & 21 & 17,4 & 36 & 25,4 & 28 & 25,9 & 21 & 25,9 & 106 & 23,5 \\
\hline Total & $\mathbf{1 2 1}$ & $\mathbf{1 0 0 , 0}$ & $\mathbf{1 4 2}$ & $\mathbf{1 0 0 , 0}$ & $\mathbf{1 0 8}$ & $\mathbf{1 0 0 , 0}$ & $\mathbf{8 1}$ & $\mathbf{1 0 0 , 0}$ & $\mathbf{4 5 2}$ & $\mathbf{1 0 0 , 0}$ \\
\hline
\end{tabular}

that consumer education is a right (which also indicates knowledge of consumer rights), the following question was asked: "To what extent are you aware that consumer education is a right?" Although most of the respondents indicated awareness to some extent $(50,1 \%)$, slightly more than a quarter $(27,8 \%)$ of the respondents were not at all aware that consumer education was a right. The respondents from the Faculty of Engineering were the least aware that consumer education was a right $(46,3 \%)$, followed by those from the Applied Sciences (25,6\%), Management (20,3\%) and Education (17,9\%) Faculties.

A significant association $(p<0,05)$ was found between respondents who indicated that consumer education was a right and those who were of the opinion that a need for consumer education for all students at a higher education institution existed. In the analysis of the question "To what extent has this right equipped you to be an informed consumer?", the majority $(91,2 \%)$ of the respondents were aware that consumer education is a right and of the opinion that the right to consumer education had equipped them (to some extent and full extent responses) to make informed decisions as consumers.

Consumer right to a healthy environment is protected For the question "To what extent do you think your consumer right to a healthy environment is protected?", $79,8 \%$ of respondents indicated that, as consumers, their right to a healthy environment was protected (to some extent and full extent responses), while $20,2 \%$ indicated that this right was not protected. In the follow-up open-ended question in which respondents had to give a reason for their answer, 52,5\% answered correctly that this right was protected (to some extent and full extent responses).

Effectiveness of the media to defend consumer rights In this five-point Likert scale question, respondents were requested to indicate their perception regarding the effectiveness of the media to defend their consumer rights. The question was: "Indicate on a scale of 1 to 5 how effective you consider the following media in defending your consumer rights to be?". Four types of media were listed, i.e. newspapers, magazines, television and radio. According to the average rank numbers resulting from Friedman's test and confirmed by the average, median and mode, television and radio (in that order) are the most effective in protecting consumer rights, followed by newspapers and magazines.

\section{Use of information and information sources}

Information gathering The next questions relate to the practice of information gathering. The first of these questions was: "How frequently do you read articles or reports in any of the following publications: Financial Mail, Business Day, South African Consumer, Business Section of newspaper, The Economist?" This question was included to determine the interest of respondents in gaining information on economic issues that impact on the consumer, which can be categorised under the consumer's right to be informed. Results indicated that most respondents did not read The Economist $(63,6 \%)$, the SA Consumer $(63,2 \%)$, the Financial Mail (55.8\%) and the Business Day $(53,2 \%)$. Most respondents $(62,0 \%)$ did read the Business Section of newspapers. It must be noted that some students indicated incorrect responses, as the Business Day and the business section of a newspaper are published daily, the Financial Mail weekly and the SA Consumer and The Economist published monthly.

The second question was as follows: "Before you buy a product (e.g. a car) or make use of a service (e.g. food delivery) that you are not familiar with, do you gather information regarding the quality and safety aspects to be able to make an informed choice?" Most respondents $(76,0 \%)$ indicated that they often and very often searched for information. Most males $(81,0 \%)$ indicated that they often to very often gathered information about a specific product or service, followed by $72,6 \%$ of female respondents. Furthermore, Afrikaans-speaking and English-speaking respondents $(79,8 \%$ and $77,7 \%$ respectively ) were found to pay more attention to gathering information, than African language respondents $(66,9 \%)$.

Information sources consulted To the question "Which information sources do you consult most frequently before you buy a product or service for the first time?" the respondents indicated that consumerdominated information sources (friends and family) were (usually and always) consulted (79,4\%). This practise is not surprising as consumer-dominated information sources are normally perceived as being trustworthy (Mason et al, 1994:145). This is followed by marketer-dominated sources such as television and radio $(58,9 \%)$. Results also indicated that respondents did not make much use of the Internet as information source $(47,7 \%$ never responses). This indicates a lack of knowledge of the wide scope of infor- 
mation sources available to assist the consumer of today in making informed decisions.

\section{Complaints and complaint resolution}

Respondents had to answer a main question and follow-up questions regarding complaints and complaint resolution which form part of the consumer rights to be heard and to seek redress. The main question was: "How often do you complain about a faulty product or poor service?" Figure 2 indicates these responses. A little less than a quarter of all respondents $(24,0 \%)$ never complained, $44,8 \%$ seldom complained and $31,2 \%$ were most likely to complain (often to very often) about a faulty product or poor service. More males $(35,8 \%)$ complained often and very often, while less $(28,3 \%)$ females reported the same. Respondents from the Faculty of Education were inclined to complain the most $(42,5 \%$ for often and very often responses), followed by the Faculty of Management (34,0\% for often and very often responses). It was also found that $47,4 \%$ of older respondents (26 years and older) were more confident about complaining about a product or a service $(47,4 \%)$, whereas, only $22,8 \%$ of the younger respondents (19 years or younger) complained often to very often.

The next question was as follows: "In respect of what product/service did you complain?" Responses indicated that if respondents did complain, it was mostly about goods $(42,3 \%)$, services $(32,1 \%)$ and food products $(25,6 \%)$. Regarding the question which followed "What was the main reason for the complaint?", complaints were mostly quality-related with regard to food products $(57,8 \%)$, followed by poor service $(26,5 \%)$ and exploitation (2,5\%). Responses to the next question "Where did you complain?" indicated that complaints were mostly channeled to the retailers or service providers $(60,1 \%)$.

The researchers also wanted to know how satisfacto- rily the complaints were resolved in order to determine how well the available channels for complaints were working as consumers have the right to redress. To the question "To what extent was your complaint resolved?", less than $20 \%$ of respondents $(19,8 \%)$ indicated that their complaints were not resolved. Females tended to be more satisfied to some or full extent $(83,4 \%)$ than males $(70,8 \%)$ regarding the extent of problem resolution. Respondents were furthermore requested to encircle the single main method used to handle their complaint. About a third of the respondents whose problems were solved to a full extent received a full refund $(34,5 \%)$, while $28,6 \%$ received a replacement and $27,7 \%$ an exchange. The respondents who indicated that their complaints had been resolved to some extent, indicated that they had in most cases received an exchange $(32,6 \%)$, while respondents whose complaints had not been resolved, had received a repaired item (23,3\%).

\section{Awareness and knowledge of South African con- sumer organisations}

Three questions about awareness and knowledge of consumer organisations were included as an assumption could be made that these respondents would be more knowledgeable about consumer rights and responsibilities. The first question was a dichotomous question where respondents had to respond "yes" or "no" to the following question: "Are you aware of consumer organisations that deal with consumer complaints?" About half $(53,9 \%)$ of the respondents had heard about consumer organisations. A little less than half $(46,1 \%)$ were unaware of such organisations. As these organisations play a vital role in the protection of the consumer, this indicates that there is a lack of awareness and that particular actions might be needed to promote their importance. More females $(74,7 \%)$ than males $(64,6 \%)$ were aware of such organisations and nearly all respondents who knew about these organisations were 26 years and older



FIGURE 2: RESPONDENT FREQUENCY OF COMPLAINING ABOUT PRODUCTS/SERVICES 
$(94,7 \%)$. The Faculty of Engineering had the most respondents $(43,1 \%)$ who had the least knowledge about consumer organisations that handle complaints. This was also the group that indicated that consumer education is not a right. The Faculty of Education was the most informed group (88,5\%) about consumer organisations.

The second question was: "Which of the following consumer organisations have you heard of?" Five recognised consumer organisations were listed. A total of 243 respondents indicated awareness of the five recognised consumer organisations. Most respondents $(87,5 \%)$ were aware of the South African Bureau of Standards (SABS), followed by the Department of Consumer Affairs (43,9\%) and the South African National Consumer Union (SANCU) (40,6\%). They were, however, ignorant regarding consumer education organisations such as the National Consumer Forum (NCF) (83\%) and the Business Practices Committee $(87,2 \%)$.

The third question related to consumer practices was: "If presented with the opportunity, would you join a consumer organisation to protect your consumer rights?" The majority of respondents $(58,4 \%)$ indicated that they were positively inclined to join a consumer organisation to protect their consumer rights. As $28,5 \%$ of the respondents indicated a "no response" to this question, it can be postulated that respondents did not understand the question or did not know what it meant to be a member of an organisation.

\section{Need for consumer education}

The last question in the questionnaire was: "Do you feel there is a need for consumer education for all students at a Higher Education institution?" The majority of respondents $(79,5 \%)$ indicated that there was such an educational need. Cognisance was taken of the Hawthorne Effect (Hawthorne effect, n.d.), which may have influenced this result. This common bias found in survey research refers to subjects responding in the way that will most please the researcher.

\section{CONCLUSIONS AND RECOMMENDATIONS}

This research was undertaken to determine the need for consumer learning at the CPUT through the use of a self-administered survey questionnaire completed by first year (NQF Level 5) students. The questionnaire was used to determine the knowledge, practices and perceptions of the students regarding consumer rights and responsibilities. This shed light on the situation analysis to establish a base for the development of curricula for consumer learning at the institution. From the perspective of a potential curriculum, the following conclusions were drawn:

- The majority of first year students (79,5\%) at CPUT indicated the need for consumer learning at all higher education institutions. They clearly saw the importance of consumer learning as a means to develop consumer competence to function effectively in the consumer-driven society of today.
- It appears that older students and African language speakers in particular, many being first generation university candidates, would benefit most from institutional consumer learning opportunities.

- The lack of knowledge among some groups of students regarding consumer rights and responsibilities did not correspond with the relatively high levels of confidence they had about expressing their consumer rights. This might be an important factor in curriculum design as people on average did not learn productively if they were unaware of their own learning gaps (Marton et al, 1997: 76; 201).

- The majority of students made use of the business section of newspapers to gather information on economic issues that impact the consumer. It is therefore important that students are informed about specialised publications which could assist them during decision making. Female students and African language speakers in particular, need consumer learning to equip them to make informed choices and be protected against dishonest and misleading advertising and labeling.

- Most students, especially younger students and females need to know about complaints and complaint resolution as part of their consumer rights to be heard and to seek redress and the consumer responsibility of action and involvement.

- The role of media, and specifically that of television should be emphasised in a consumer learning curriculum as a mechanism to protect consumer rights and responsibilities.

- Awareness regarding the consumer right to basic needs (food, housing, clothing, healthcare, education and drinking water) should be created through the selection of appropriate learning content in a consumer learning curriculum.

- Consumer education/learning as a consumer right is of critical importance and should be emphasised in the consumer learning experience.

- The majority of students indicated that their right to a healthy environment is protected; however, all students would benefit from activities which promote a healthy environment for future generations.

- An important aspect which needs to be focused on in a curriculum for consumer learning is knowledge of SA consumer organisations and what it means to be a member of an organisation.

- As CPUT students were largely unaware of consumer organisations and consumer information sources, it is recommended that the electronic media, especially the Internet, be introduced to students (together with other media) as an additional information source over and above advice from friends and family.

The survey furthermore contributed to the development of a curriculum framework for consumer learning at a higher education institution (Crafford, 2006: 217). This framework is compatible with the requirements of the South African Qualifications Authority and the Higher Education Qualifications Framework. It is therefore recommended that the needs assessment serve as a guideline for the development of consumer learning programmes at the CPUT and other higher education institutions in South Africa and on the conti- 
nent of Africa as Africans face unique challenges and are best suited to develop their own strategies to empower future consumers.

\section{REFERENCES}

ATHERTON, M \& WELLS, J. 1998. Consumer education: learning for life. Consumer Policy Review 8 (4):127-131.

BABBIE, E. 1990. Survey research methods. Belmont, California. Wadsworth Publishing.

BABBIE, E. 1992. The practice of social research. 6th ed. Belmont, California. Wadsworth Publishing.

BANNISTER, R. 1996. Consumer education in the United States: a historical perspective. Available on line. URL: http://www.nice.emich.emich.edu/benefits.html. Accessed 11 March 2003.

BANNISTER, R \& MONSMA, C. 1982. Classification system for consumer education concepts. Available on line. URL: http://www.emich.edu/public/coe/nice/ mission.html. Accessed 01 June 2002.

BITZER, EM. 2003. Assessing students' changing perceptions of higher education. South African Journal of Higher Education 17(3):164-177.

BITZER, EM. 2005. First-year students' perceptions of generic skills competence and academic performance: a case study at one university. South African Journal of Higher Education 19(3):172-187.

BITZER, EM \& TROSKIE-DE BRUIN, C. 2004. The effect of factors related to prior schooling on student persistence in higher education. South African Journal of Education 24(2):119-125.

CHAN, PW. 2001. Consumers International. (Speech). Available on line. URL: http://www.ncf.org.za/docs/publication/saconsumer/2003/april/food/ chan.html. Accessed 19 July 2003.

CONSUMERS INTERNATIONAL. 1999. The rights and responsibilities of consumers. Available on line. URL: $\quad$ http://www.193.128.6150/consumers/about/ rights.html. Accessed 20 January 2004.

CONSUMERS INTERNATIONAL. 2003. World Consumer Rights Day: History and Purpose. Available on line. URL: http://www.consumersinternational.org. Accessed 20 June 2003.

COPPACK, M. 2002. Complementing information and advice. Advisor 91:49-52.

CRAFFORD, S. 2006. A curriculum framework for consumer learning at a higher education institution. PhD thesis. University of Stellenbosch.

DENSCOMBE, M. 2001. The good research guide for small scale social research projects. Buckingham. Open University Press.

DEPARTMENT OF EDUCATION (DoE). 2005. National Curriculum Statement Grades 10-12 (general): Learning programme Guidelines - Consumer Studies. Pretoria. Government Printer.

GREENACRE, MJ. 1984. Theory and applications of correspondence analysis. New York. Academic Press. GIVENS, B. 2004. RE: Financial literacy and education campaign strategies. Comments submitted. Available on line. URL: http://www.privacyrights.org/ prvindexfile.search. Accessed 06 March 2006.

HAWTHORNE EFFECT. n.d. Available on line. URL: http://www.edusurvey.net/tips.htm. Accessed 18 July 2006.

HAYWARD, J \& COPPACK, M. 2001. Consuming passions. Teaching Citizenship 48-51.
HELLMAN-TUITERT, G. 1999. Promoting consumer education in schools. Stockholm. Katarina Tryck AB.

HUYSAMEN, GK. 1994. Methodology for the social and behavioural sciences. Pretoria. Sigma Press.

LACHANCE, MJ \& CHOQUETTE-BERNIER, N. 2004. College students' consumer competence: a qualitative exploration. International Journal of Consumer Studies 28(5):433-442.

MARTON, F, HOUSELL, D \& ENTWISTLE, N. 1997.

The experience of learning. Implications for teaching and studying in higher education. 2nd ed. Edinburgh. Scottish Academic Press.

MASON, JB, MAYER, ML \& EZELL, HF. 1994. Retailing. 5th ed. Boston. Massachusetts. Irwin.

NICE-MAIL 1 (News and Information about Consumer Education). 1994. The importance of investigation: a Swedish study: "Tomorrow's consumers of today". 1/1994.

NICE-MAIL 15 (News and Information about Consumer Education). 2001. More financial education needed for youngsters (Finland). 15/2001.

NICE-MAIL 18 (News and Information about Consumer Education. 2002. CE: Complementing information and advice (UK). 18/2002.

NICE-MAIL 19 (News and Information about Consumer Education). 2003. Communicating with young people (Sweden). 19/2003.

OPPENHEIM, AN. 1992. Questionnaire design, interviewing and attitude measurement. London. Printer Publishers.

ROUSSEAU, D. 1999. Consumerism and social responsibility. In Du Plessis, PJ \& Rousseau, GG. 1999. Buyer behaviour. A multi-cultural approach. Johannesburg. Thomson.

SCHNETLER, J. 1989. Principles of constructing questions and questionnaires. In Schnetler, J. 1989. Survey methods and practice. Cape Town. Human Sciences Research Council.

SCHUTTE, De W. 1992. Notes on the dendrogram technique for the development of questionnaires. Cape Town. Human Sciences Research Council.

STATSOFT, INC. 2005. STATISTICA (Data analysis software system), version 7.1. Available on line. URL: http://www.statsoft.com. Accessed 25 January 2005.

SINGLETON, RA, STRAITS, BC \& STRAITS, MM. 1993. Approaches to social research. New York. Oxford University Press.

STEFFENS, H. 1993. Consumer education - basis distinctions. Paper presented at European Conference on Consumer Education in Schools. Stockholm.

STRUWIG, FW \& STEAD, GB. 2001. Planning, designing and reporting research. Cape Town. Maskew Miller Longman.

STOKER, DJ. 1989. Basic sampling methods. In Schnetler, J. 1989. Survey methods and practice. Opinion Survey Centre, Human Sciences Research Council.

UNITED NATIONS. 1985. Guidelines for consumer protection. Department of International Economic and Social Welfare. New York. United Nations. Available on line. URL: http://www.un.org/esa/sustdev/sdissues/ consumption/cppgoph3.htm. Accessed 20 November 2004.

UNITED NATIONS. 2003. United Nations Guidelines for Consumer Protection (as expanded in 1999). Department of Economic and Social Affairs. New York. United Nations. Available on line. URL:

http://www.un.org/esa/sustdev/publications/ consumption_en.pdf. Accessed 20 November 2005. 